\title{
Efektifitas Terapi Kelompok Terapeutik (TKT) Usia Dewasa Terhadap Kesejahteraan Ibu Pekerja
}

\author{
Muhammad Ari Arfianto ${ }^{1}$, Rudianingseh ${ }^{2}$ \\ ${ }^{1,2}$ Fakultas Keperawatan dan Kebidanan Universitas Nahdlatul Ulama Surabaya
}

Korespondensi penulis: $\underline{\text { muslim.ari@gmail.com }}$

\begin{abstract}
Abstrak
Masalah kesejahteraan hidup merupakan fenomena yang sering terjadi pada kehidupan ibu pekerja akibat adanya peran yang berlebih. Terapi Kelompok Terapeutik (TKT) usia dewasa merupakan pendekatan kegiatan kelompok pada ibu pekerja yang akan diteliti efektifitasnya dalam mempengaruhi kesejahteraan ibu pekerja. Tujuan dari penelitian ini adalah menganalisis efektifitas terapi kelompok terapeutik terhadap kesejahteraan subjektif dan psikologis pada ibu pekerja. Desain penelitian yang digunakan adalah kuantitatif dengan rancangan quasi experiment. Jumlah sampel adalah 62 orang yang dibagi menjadi kelompok perlakuan dan kontrol. Pengambilan sampel dengan metode purposive sampling pada ibu pekerja di wilayah Kabupaten Sidoarjo. Variabel dianalisis dengan paired $t$ test dan independent $t$ test. Hasil penelitian ini adalah terdapat pengaruh yang signifikan terapi kelompok terapeutik usia dewasa terhadap peningkatan kesejahteraan subjektif dan psikologis ibu pekerja ( $p$ value: 0,000). Penelitian ini merekomendasikan kepada pelayanan keperawatan jiwa masyarakat maupun perusahaan yang mempekerjakan ibu rumah tangga untuk menyediakan pelayanan kesehatan jiwa serta dilaksanakannya terapi kelompok terapeutik dalam membantu ibu pekerja mencapai kesejahteraan subjektif dan psikologis.
\end{abstract}

\section{Kata kunci : terapi kelompok terapeutik; kesejahteraan; ibu pekerja}

\section{PENDAHULUAN}

Peningkatan jumlah usia produktif atau usia dewasa yang tidak diimbangi dengan pertumbuhan lapangan pekerjaan ternyata memberikan dampak peningkatan persaingan sosial ekonomi. Duflo (2012) menyebutkan bahwa tuntutan ekonomi tersebut merupakan salah satu alasan utama pemberdayaan kaum wanita dalam angkatan kerja sehingga perempuan mulai banyak ambil bagian dalam dunia kerja. Menurut Floro \& Meurs (2009) dalam Global Employment Trend for Women menyebutkan bahwa tingkat partisipasi perempuan dalam angkatan kerja di berbagai negara saat ini menunjukkan peningkatan. Perubahan sosial yang terjadi membuat wanita memiliki peluang untuk menjalankan peran ganda, yaitu peran utamanya sebagai ibu dan istri serta peran sebagai pekerja.

Di Eropa terjadi kenaikan prosentase pekerja wanita dari 53,7 persen pada tahun 2002 menjadi 64,3 persen di tahun 2011. Fenomena ibu rumah tangga yang bekerja atau wanita karir ini juga banyak ditemukan di Indonesia, Terdapat 43 juta pekerja wanita dari 112 juta pekerja di Indonesia (Badan Pusat Statistik, 2013).

Umumnya seorang ibu rumah tangga memilih untuk bekerja dengan harapan dapat meningkatkan kesejahteraan diri dan keluarga. Tetapi masalah besar yang paling dirasakan oleh ibu yang bekerja adalah timbulnya konflik peran dan beban yang berlebih. Konflik peran yang ditimbulkan dapat berupa ketidaksesuaian antara tekanan, 
tuntutan dan harapan yang ada di rumah dengan yang ada di tempat kerja, adanya tuntutan dalam waktu yang bersamaan antara peran sebagai ibu, istri dan bekerja. Sedangkan kelebihan beban disebabkan karena tuntutan energi dan waktu yang melebihi kapasitas yang dimiliki seorang ibu. Hal ini juga menunjukkan bahwa adanya konflik peran dan beban yang berlebih akan menimbulkan dampak negatif bagi ibu yang bekerja, dampak tersebut dapat berupa stres, perasaan tertekan, letih (O’Brien, 2010).

Penelitian yang lain juga menyebutkan tentang adanya dampak bekerja pada gejala depresif, stres akibat pekerjaan dan kualitas tidur pada wanita (Ho-Sung, dkk 2013), dampak bekerja terhadap konflik keluarga dan kerja pada pekerja wanita (Mjoli, Dywili \& Dodd, 2013), ibu yang bekerja juga berkaitan dengan keterlambatan anak dalam belajar berbicara (Suparmiati, Ismail \& Sitaresmi, 2013).

Berbagai dampak tersebut merupakan penyebab penurunan dari kesejahteraan diri seseorang. Jika tujuan seorang ibu yang mengambil peran bekerja adalah untuk mencapai kesejahteraan diri, maka dampak yang diakibatkan dari peran tambahan tersebut justru menghambat tercapainya kesejahteraan diri. Nordenmark, Vinberg dan Strandh (2012) menyatakan bahwa peningkatan stress psikososial dalam pekerjaan mempengaruhi keseimbangan dalam hidup dan menurunkan kesejahteraan diri.

Menurut Kamus Besar Bahasa Indonesia (2017) kesejahteraan diartikan sebagai suatu hal atau keadaan sejahtera, keamanan, keselamatan, ketenteraman, kesehatan jiwa, keadaan sejahtera masyarakat. Dalam psikologi, kesejahteran ini diartikan menjadi dua pendapat yaitu hedonic dan eudaimonic.
Perspektif hedonic mengartikan kesejahteraan diri sebagai sesuatu yang subjektif, maksudnya apabila seseorang secara subjektif merasa dirinya sejahtera atau bahagia maka dia dikatakan sejahtera. Kesejahteraan diri ini disebut sebagai "Subjective Well-being (SW)" atau kesejahteraan subjektif.

Diener (2009) menjelaskan kesejahteraan subjektif sebagai suatu penilaian terhadap hidup seseorang, meliputi penilaian kognitif dan penilaian afektif. Penilaian kognitif dilihat dari kepuasan hidup yang dinyatakan dengan pernyataan yang mengindikasikan kepuasan dari aspekaspek kehidupan. Penilaian afektif dinilai dari pengalaman emosional yang dialami dalam waktu tertentu yang dapat berupa afek positif dan negatif.

Deci dan Ryan (2008) menjelaskan kesejahteraan diri dari perspektif eudaimonic. Kesejahteraan diri dapat dicapai jika seseorang tersebut mampu memanfaatkan potensi-potensi yang ada di dalam diri orang tersebut. Kesejahteraan diri ini disebut sebagai "Psychological Well-being (PW)" atau kesejahteraan psikologis. Huppert (2009) menjelaskan bahwa kesejahteraan psikologis sebagai suatu kehidupan yang berjalan bahagia, yaitu merupakan kombinasi dari perasaan senang dan berfungsi baik dalam kehidupan. Ryff, Keyes dan Shmotkin (2002) kemudian menjelaskan bahwa kesejahteraan psikologis ditandai dengan mempunyai penerimaan diri yang positif, hubungan yang baik dengan orang lain, mampu memutuskan sesuatu dengan standar dirinya sendiri, mampu menciptakan lingkungan yang sesuai dengan kondisi psikologisnya, mempunyai arti dan tujuan hidup, serta mengalami perkembangan potensi.

Kesejahteraan tidak hanya dipengaruhi oleh faktor materi atau sosial ekonomi tetapi yang lebih penting 
adalah masalah kesehatan jiwa individu. Individu dengan tingkat kesehatan jiwa yang baik akan mampu mengatasi stres akibat kerja sehingga akan mampu mencapai kondisi sejahtera secara subjektif maupun psikologis. Untuk meningkatkan kesejahteraan diri ibu pekerja adalah dengan cara meningkatkan mekanisme koping. Metode yang dapat digunakan untuk meningkatkan mekanisme koping ibu pekerja adalah dengan adanya psikoterapi berbasis kelompok atau disebut juga dengan Terapi Kelompok Terapeutik (TKT) untuk kelompok usia dewasa.

Terapi Kelompok Terapeutik (TKT) merupakan salah satu jenis terapi kelompok yang memberikan kesempatan kepada anggotanya untuk saling berbagi pengalaman, saling membantu satu dengan yang lainnya, untuk menemukan cara menyelesaikan masalah dan mengantisipasi masalah yang akan dihadapi dengan mengajarkan cara yang efektif untuk mengendalikan stres. Terapi Kelompok Terapeutik (TKT) usia Dewasa lebih khusus diperuntukan untuk kelompok usia dewasa. kegiatan kelompok ini lebih berfokus pada hubungan di dalam kelompok, interaksi antar anggota kelompok dan pertimbangan isu yang selektif (Townsend, 2009). Metode dengan pendekatan kegiatan berkelompok sering dilakukan oleh praktisi kesehatan jiwa dalam menyelesaikan berbagai masalah kejiwaan pada kelompok usia seperti pada kelompok usia anak, mengatasi perilaku remaja, mengatasi kecemasan pasien hospitalisasi, depresi lansia dll, tetapi belum pernah dilakukan untuk mengatasi masalah kesejahteraan pada ibu pekerja.

Terapi Kelompok terapeutik sebelumnya telah diteliti dan menunjukkan pengaruh signifikan pada kemampuan keluarga dalam menstimulasi perkembangan anak usia toodler (Trihadi, Keliat \& Susanti, 2009), meningkatkan adaptasi ibu hamil (Susmiatin, Keliat \& Susanti, 2010), meningkatkan perkembangan intimasi dewasa muda (Agustine, Daulima \& Gayatri, 2012), meningkatkan kemampuan mengendalikan emosi marah pada remaja (Wiyata, Mustikasari \& Wardani, 2014), meningkatkan kecerdasan emosi remaja (Astutik, Daulima \& Hayuni, 2015), meningkatkan perkembangan inisitif anak usia prasekolah (Damayanti, Hastono \& Susanti, 2010), meningkatkan keterampilan fase industri pada anak usia sekolah (Walter, Keliat \& Hastono, 2010), meningkatkan adaptasi keluarga dan kemampuan integritas diri lansia (Pase, Keliat \& Pujasari, 2013).

Penelitian sebelumnya yang dilakukan oleh Arfianto, Mustikasari dan Wardani (2015) pada ibu pekerja di kabupaten Sidoarjo menunjukkan bahwa ibu pekerja mempunyai skor kesejahteraan subjektif dan psikologis yang rendah. Dari penelitian tersebut juga didapatkan hasil bahwa faktor persepsi ibu pekerja pada dukungan keluarga, teman, kelompok dan orang spesial menjadi faktor yang paling dominan. Rendahnya persepsi individu merupakan tanda bahwa penilaian kognitif ibu pekerja kurang. Kurangnya penilaian kognitif tersebut disebabkan karena mekanisme koping ibu pekerja dalam menghadapi stres masih kurang. Oleh karena itu dibutuhkan strategi peningkatan mekanisme koping ibu pekerja tersebut, salah satunya dengan kegiatan terapi kelompok terapeutik. Dengan latar belakang di atas, peneliti akan melakukan penelitian tentang Efektifitas Terapi Kelompok Terapeutik (TKT) Usia Dewasa terhadap 
Muhammad Ari Arfianto, Rudianingseh

Efektifitas Terapi Kelompok Terapeutik (TKT) Usia Dewasa Terhadap Kesejahteraan Ibu Pekerja

Kesejahteraan Ibu Pekerja di Kabupaten Sidoarjo.

\section{METODE}

Desain yang digunakan dalam penelitian adalah quasi experiment. Populasi target dalam penelitian ini adalah seluruh wanita yang bekerja sebagai di wilayah Kabupaten Sidoarjo. Jumlah sampel pada penelitian ini adalah 62 responden yang dibagi menjadi dalam kelompok perlakuan dan kontrol. Responden diambil dengan metode purposive sampling di Kelurahan Sidokare Kabupaten Sidoarjo dengan kriteria berusia 26 sampai 65 tahun, menikah atau pernah menikah, masih aktif bekerja.

Data pre dan post tes diambil dengan menggunakan kuesioner yang terdiri dari kuesioner demografi, kuesioner Oxford Happiness Questionnaire (OHQ), yang dikembangkan oleh Arglye dan Hills (2002) untuk mengukur kesejahteraan subjektif, dan kuesioner Ryff's Scale Psychological Well-Being (RPWB) yang diciptakan pertama kali oleh Ryff dan dikembangkan oleh Siefert pada tahun 2005 untuk mengukur kesejahteraan psikologis.

Responden kelompok perlakuan kemudian dilakukan Terapi Kelompok Terapeutik (TKT) Usia Dewasa yang terdiri dari 6 sesi. Sesi 1 mengkaji perkembangan masing-masing anggota yang telah dicapai dan upaya memenuhi tugas perkembangannya, sesi 2 berdiskusi tentang stimulasi perkembangan biologis dan psikoseksual, sesi 3 berdiskusi tentang stimulasi perkembangan kognitif dan bahasa, sesi 4 berdiskusi tentang stimulasi perkembangan moral spiritual, sesi 5 berdiskusi tentang stimulasi perkembangan emosi dan psikososial dan sesi 6 diskusi evaluasi cara stimulasi yang telah diajarkan dan apa manfaatnya.

Prinsip etik yang digunakan pada penelitian ini adalah beneficience, maleficiency, autonomy, anonymity, dan justice. Penelitian ini telah lulus uji etik dari komite etik sebelum dilakukan penelitian. Analisa data yang digunakan untuk menguji hipotesis adalah korelasi Pearson Product Moment.

\section{HASIL}

1. Karakteristik responden

Karakteristik responden dalam penelitian ini dijelaskan pada tabel berikut ini.

Tabel 1. Rata-rata karakteristik umur, jumlah anak dan penghasilan per bulan

\begin{tabular}{lcc}
\multicolumn{3}{c}{$(\mathbf{n = 6 2})$} \\
\hline Karakteristik & $\begin{array}{c}\text { Intervensi } \\
(\mathbf{n}=\mathbf{3 1})\end{array}$ & $\begin{array}{c}\text { Kontrol } \\
(\mathbf{n = 3 1})\end{array}$ \\
\hline Usia & 36,48 & 37,65 \\
\hline Jumlah anak & 2,26 & 2,00 \\
\hline $\begin{array}{l}\text { Jumlah } \\
\text { penghasilan }\end{array}$ & 2.329 .032 & 2.512 .903 \\
\hline
\end{tabular}

Tabel 2. Karakteristik status, suku, pendidikan, pekerjaan $(n=62)$

\begin{tabular}{llcc}
\hline \multicolumn{2}{c}{ Karakteristik } & $\begin{array}{c}\text { Intervensi } \\
(\mathbf{n = 3 1})\end{array}$ & $\begin{array}{c}\text { Kontrol } \\
(\mathbf{n = 3 1})\end{array}$ \\
\hline Status & Menikah & $28(90,3)$ & $30(96,8)$ \\
& Janda & $3(9,7)$ & $1(3,2)$ \\
\hline Suku asal & Jawa & $29(93,6)$ & $27(87,1)$ \\
& Madura & $1(3,2)$ & $3(6,7 \%)$ \\
& Lain-lain & $1(3,2)$ & $1(3,2)$ \\
\hline Tingkat & SMA & $8(25,8)$ & $4(12,9)$ \\
penddikan & Perguruan & $10(32,3)$ & $14(45,2)$ \\
& tinggi & $13(41,9)$ & $13(41,9)$ \\
\hline Jenis & Swasta & $19(61,3)$ & $19(61,3)$ \\
pekerjaan & Wiraswasta & $9(29,0)$ & $7(22,6)$ \\
& PNS & $3(9,7)$ & $5(16,1)$ \\
\hline
\end{tabular}

2. Pengaruh Terapi Kelompok Terapeutik (TKT) Usia Dewasa pada Kesejahteraan Subjektif Ibu Pekerja

Hasil uji statistik kelompok perlakuan dan kontrol sebelum dan sesuadah mendapatkan Terapi 
Muhammad Ari Arfianto, Rudianingseh

Efektifitas Terapi Kelompok Terapeutik (TKT) Usia Dewasa Terhadap Kesejahteraan Ibu Pekerja

Kelompok Terapeutik adalah sebagai berikut

Tabel 3. Kesejahteraan Subjektif Ibu

Pekerja yang mendapatkan Terapi

Kelompok Terapeutik (TKT) Usia

Dewasa dan kelompok Kontrol $(n=62)$
Tabel 4. Kesejahteraan Psikologis Ibu

Pekerja yang mendapatkan Terapi

Kelompok Terapeutik (TKT) Usia

Dewasa dan kelompok Kontrol $(n=62)$

\begin{tabular}{|c|c|c|c|c|c|c|}
\hline \multirow[t]{2}{*}{ Sub variabel } & & \multicolumn{2}{|c|}{ Pre tes } & \multicolumn{2}{|c|}{ Pos tes } & \multirow{2}{*}{$p$-value } \\
\hline & & Mean & SD & Mean & SD & \\
\hline \multicolumn{7}{|c|}{ INTERVENSI } \\
\hline Penerimaan diri & 31 & 26,10 & 4.29 & 28,61 & 1,54 & 0,004 \\
\hline Hubungan & 31 & 26,58 & 3,69 & 29,68 & 2,26 & 0,000 \\
\hline
\end{tabular}

positi

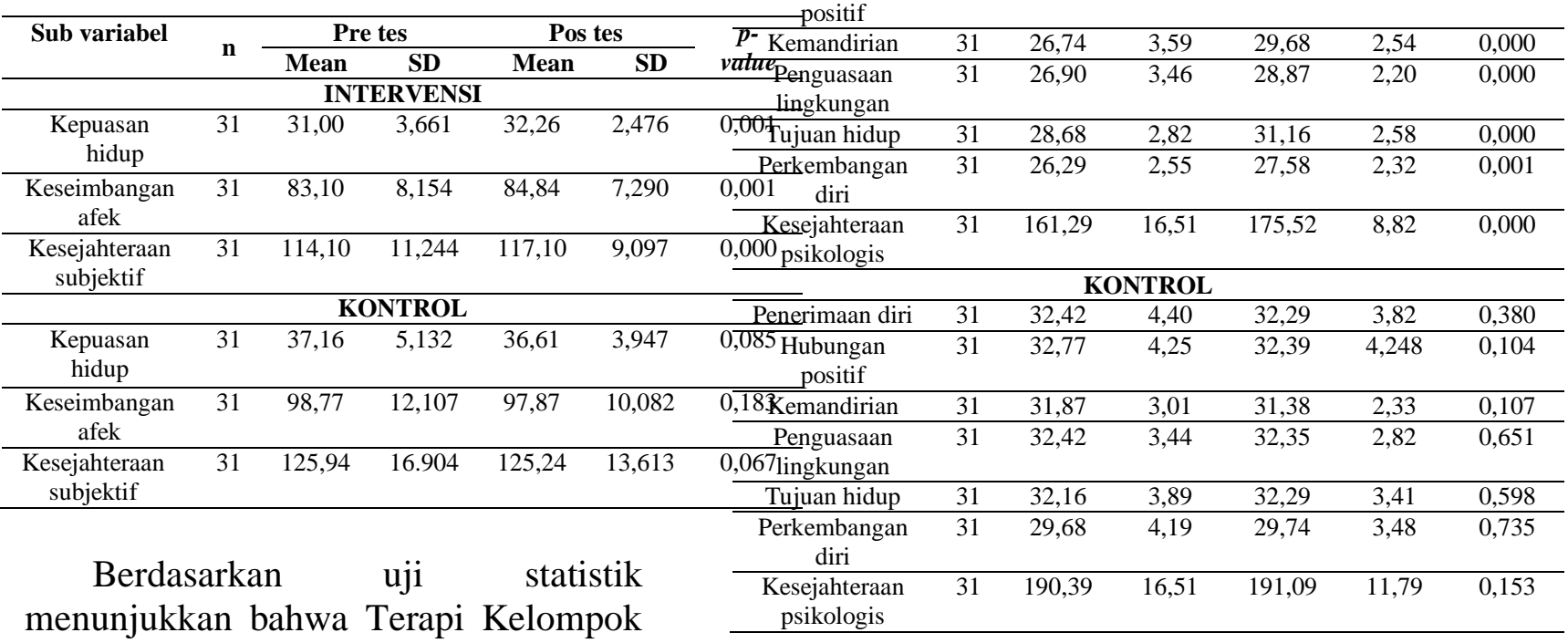

Terapeutik (TKT) Usia Dewasa secara signifikan mempengaruhi peningkatan kesejahteraan subjektif ibu pekerja baik pada aspek kepuasan hidup maupun keseimbangan afek dengan nilai $p$ value $<0,05$.

3. Pengaruh Terapi Kelompok Terapeutik (TKT) Usia Dewasa pada Kesejahteraan Psikologis Ibu Pekerja

Hasil uji statistik kelompok perlakuan dan kontrol sebelum dan sesuadah mendapatkan Terapi Kelompok Terapeutik adalah sebagai berikut:
Berdasarkan uji statistik menunjukkan bahwa Terapi Kelompok Terapeutik (TKT) Usia Dewasa secara signifikan mempengaruhi peningkatan kesejahteraan psikologis ibu pekerja baik pada aspek penerimaan diri, hubungan yang positif, kemandirian, penguasaan lingkungan, penguasaan tujuan hidup dan perkembangan diri dengan nilai $\mathrm{p}$ value $<0,05$.

\section{PEMBAHASAN}

Hasil penelitian menunjukkan bahwa rata-rata kesejahteraan subjektif dan psikologis pada responden kelompok perlakuan mengalami peningkatan jika dibandingkan dengan kelompok kontrol, hal tersebut juga didukung dengan hasil uji statistik dengan nilai $p$ value 0,000 . Dengan demikian karena nilai $p$ value lebih kecil dari pada $\alpha$, maka dapat disimpulkan bahwa Terapi Kelompok Terapeutik (TKT) usia dewasa eektif meningkatkan kesejahteraan ibu 
pekerja, baik kesejahteraan subjektiff maupun psikologis.

Kesejahteraan subjektif terdiri dari dimensi kepuasan hidup dan keseimbangan afek, sedangkan kesejahteraan psikologis terdiri dari dimensi penerimaan diri, hubungan positif, kemandirian, penguasaan lingkungan, perkembangan diri dan pemahaman tujuan hidup. Seluruh dimensi tersebut merupakan kriteria sehat jiwa menurut WHO. Dengan demikian seseorang yang mempunyai skor kesejahteraan subjekti dan psikologis yang semakin tinggi berarti mempunyai kesehatan jiwa yang lebih baik pula. Kondisi kesehatan jiwa seseorang sangat dipengaruhi oleh faktor biologis, psikologis dan sosial budaya (Stuart, 2013). Pemberian terapi berbasis kelompok merupakan cara yang sering dilakukan pada berbagai pelayanan kesehatan jiwa untuk meningkatkan koping klien.

Jenis pendekatan terapi kelompok terapeutik yang digunakan pada terapi ini kelompok ini adalah kelompok konseling tidak langsung yaitu melalui aktifitas, seperti permainan, klub, keterampilan, pengajaran dan pelatihan, serta kelompok kerja, yang menekankan tidak hanya dalam memecahkan masalah tatapi juga pengalaman nyata. Kelompok ini untuk menyesuaikan atau merubah gaya hidup.

Menurut Fleitman (2009) terapi kelompok dilakukan dengan sangat bersahabat, relaks, saling berbagi, terbuka dan tanpa tekanan lingkungan. Hal tersebut akan membantu indivvidu dan keluarganya menciptakan hubungan yang lebih baik. Menciptakan terapi kelompok dengan suasana menyenangkan, bersahabat, santai membuat responden ibu pekerja merasa tidak tertekan sehingga menjadi suasan dinamis dan interaktif.
Segalah permasalahan dapat disampaikan dengan terbuka dan tanpa rasa takut dan malu pada anggota kelompok yang lain.

Terapi kelompok terapeutik adalah terapi yang fokus utamanya untuk mencegah gangguan dengan mengajarkan cara yang efektif untuk mengatasi stress emosional pada suatu situasi atau krisis perkembangan (Townsend, 2009). Terapi kelompok terapeutik merupakan salah satu jenis dari terapi kelompok yang memberi kesempatan kepada anggotanya untuk saling berbagi pengalaman, saling membantu satu dengan lainnya, untuk menemukan cara menyelesaikan masalah dan mengantisipasi masalah yang akan dihadapi dengan mengajarkan cara yang efektif untuk mengendalikan stres.

Kelompok merupakan lingkungan yang alamiah bagi responden ibu pekerja. Kelompok dapat berperanpenting dalam mempengaruhi hubungan antar anggotanya. Merujuk pendapat Crokkett(1984 dalam Jonhnson, 1995) interaksi kelompok dapat memberi kesempatanperkembangan psikologis responden ibu pekerja seperti pembentukan hubungan sosial, ketrampilansosial, meningkatkan interaksi sosial, dan memahami diri dan orang lain. Kelompok adalahkumpulan individu yang memiliki hubungan satu dengan yang lainnya, salingketergantungan dan mempunyai norma (Stuart, 2009).

Sedangkan menurut Varcarolis, Carson, \& Shoemaker (2006) kelompok adalah dua atau lebih orang yangmengembangkan hubungan interaktif dan berbagi tujuan atau masalah. Ada bermacam-macam kelompok salah satunya kelompok sebaya. dewasa keterikatannyasangat kuat dengan kelompok sebayanya. 
Potensi masalah dan sumber koping dapatberasal dari kelompok sebaya. Usia dewasa adalah makhluk sosial yang mempunyai ketrampilan sosial, mereka sering lebih mempercayai teman sebaya dibanding orang yang lebih memahami (Fleitman, 2009). Koping individu dapat dibentuk dari cara dia memandang dan berespon terhadap orang lain dalam kelompok (Jonhnson, 1995).

Sebagai upaya menangani masalah perkembangan yang dihadapi responden pendekatan terapi kelompok sangat tepat dipilih. Terapi kelompok terapeutik merupakanpilihan ideal dan penting bagi kelompok umur ini. Mereka menjadi mampu belajar antarsatu sama lain sesuai perkembangan mereka (Wood, 2009), dapat membantu individu dalam memenuhi kebutuhannya secara positif, bermakna bagi kelompok sebaya danpembentukan identitas diri (Stuart, 2009). Untuk memenuhi pemenuhan kebutuhan perkembangan usia dewasa muda agar dapat menjalankan kehidupannya dengan optimal diperlukan latihan atau stimulasi melalui terapi kelompok terapeutik, dalam terapi kelompok terapeutik ini membutuhkan peran serta individu secara aktif.

Selain itu, peran perawat sebagai terapis juga sangat berpengaruh. Kemampuan perawat untuk memodifikasi kegiatan dalam kelompok agar menarik dan tidak membosankan adalah hal yang harus diperhatikan oleh terapis sehingga menimbulkan rasa ingin tahu dan motivasi yang tinggi dari tiap anggota untuk mengikuti setiap kegiatan kelompok yang telah direncanakan.

\section{KESIMPULAN}

Pada penelitian ini menunjukkan bahwa Terapi Kelompok Terapeutik (TKT) Usia Dewasa berpengaruh signifikan dalam meningkatkan kesejahteraan subjektif dan psikologis ibu pekerja. Penelitian ini memberikan implikasi keperawatan tentang pentingnya perhatian pada kesehatan jiwa ibu pekeraja.

Pelayanan kesehatan di komunitas pada umumnya masih lebih memprioritaskan kesehatan fisik. Penelitian ini dapat digunakan sebagai acuan untuk memberikan pelayanan kesehatan jiwa bagi ibu pekerja. Kesejahteraan ibu pekerja sangat penting karena terkait dengan ketahanan keluarga. Perawat jiwa komunitas dapat mengembangkan Terapi Kelompok Terapeutik (TKT) Usia Dewasa untuk meningkatkan kesejahteraan subjektif dan psikologis.

\section{DAFTAR PUSTAKA}

Agustine, E., Daulima, N.H.C., \& Gayatri, D. (2012). Pengaruh Terapi Kelompok Terapeutik Dewasa terhadap Perkembangan Intimasi pada Mahasiswa Akper Subang dan Sumedang Jawa Barat. Tesis FIK Universitas Indonesia.

Arfianto, M.A., Mustikasari \& Wardani, I.Y (2015). Hubungan Sumber dan Bentuk Dukungan Sosial dengan Kesejahteraan Ibu Pekerja Di Kabupaten Sidoarjo. Tesis FIK Universitas Indonesia.

Astitik, W., Daulima, N.H.C., \& Hayuni (2015). Pengaruh Terapi Kelompok Terapeutik Remaja terhadap Kecerdasa Emosi Remaja Kota Depok. Tesis FIK Universitas Indonesia.

Badan Perencanaan Pembangan Nasional (2013). Proyeksi Penduduk Indonesia (Indonesia 
Muhammad Ari Arfianto, Rudianingseh

Efektifitas Terapi Kelompok Terapeutik (TKT) Usia Dewasa Terhadap Kesejahteraan Ibu Pekerja

Population Pojection) 2010 2035. Jakarta: Bappenas.

Badan Pusat Statistik (2011). Indonesia Dalam Angka. Diakses 18 Desember 2014, dari www.bps.go.id.

Badan Pusat Statistik Kabupaten Sidoarjo (2013). Indeks

Pembangunan Gender (IPG) Kabupaten Sidoarjo 2013. Sidoarjo: BPS.

--------- (2014). Statistik Daerah Kabupaten Sidoarjo 2014.

Sidoarjo: BPS.

Cavanaugh, J.C, \& Blanchard, F. (2011). Adult Development and Aging, Sixth Edition. Belmont: Wadsworth.

Deci, E. L., \& Ryan, R. M. (2008). Hedonia, eudaimonia, and wellbeing: An introduction. Journal of Happiness Studies vol. 10.1007.

Damayanti, Keliat, B.A., \& Susanti, H. (2010). Pengaruh Terapi Kelompok Terapeutik terhadap Perkembangan Inisiatif Anak Prasekolah di Lampung. Tesis FIK Universitas Indonesia.

Diener, E. (2009). Assessing well-being: defining and measuring subjective well-being (social indicators research series). New York: Springer.

Duflo, E (2012). Women Empowerment and Economic Development. Journal of Economic Literature 2012, 50(4), 1051-1079.

Floro, M.S., \& Meurs, M. (2009). Global Trends In Women's Access to "Decent Work". Geneva: ILO.

Ho-Sung C, et. al. (2013). The relationship between depressive symptoms among female workers and job stress and sleep quality. Annals of Occupational and Environmental Medicine Vol. 25 No. 12.
Huppert, F. A. (2009). Psychological well-being: Evidence regarding its causes and consequences. Applied Psychology:Health and WellBeing.

Kamus Besar Bahasa Indonesia Online (2017). Diakses tanggal 3 Juli 2017. http://kbbi.web.id/sejahtera

Mjoli, T., Dywili, M., \& Dodd, N., (2013). Demographic Determinants of Work-Family Conflict among Female Factory Workers in South Africa. Journal of Economics, Business and Management, Vol. 1, No. 1.

Nordenmark, M., Vinberg, S., \& Strandh, M. (2012). Job control and demands, work-life balance and wellbeing among selfemployed men and women in Europe. Health Sciences, Mid Sweden University, SE-831 25.

O'Brien, G. E. (2010). Psychology of work and unemployment. New York: John Wiley \& Sons .

Papalia, D.E., Old, S.W., \& Feldman, R.D. (2009). Human Development (11 $1^{\text {th }}$ Edition). Newyork, : McGraw Hill.

Pase, M., Keliat, B.A., \& Pujasari, H. (2013). Pengaruh Terapi Kelompok Terapeutik dan Psikoedukasi Keluarga Terhadap Inegritas Diri Lansia Kelurahan Tanah Baru Bogor. Tesis FIK Universitas Indonesia.

Perry, A.G \& Potter, P.A, (2009). Fundamental of Nursing $7^{\text {th }}$ edition. St Louis: Mosby.

Pontin, E., Schwannauer, M., Tai, S., \& Kinderman, P. (2013) A UK validation of a general measure of subjective well-being: the modified BBC subjective wellbeing scale (BBC-SWB). Liverpool: Health and Quality of Life Outcomes vol. 11:150. 
Ryff, C.D. \& Singer, B. (1996). Psychological Well-Being: Meaning, Measurement, and Implication for psychotherapy Research. Institute of Aging Madial Science Center Univercity Avenue Madison.

Ryff, C.D. \& Singer, B. (2008). Know thyself and become what you are: a eudaimonic approach to psychological well-being. Journal of Happiness Studies vol. 9: 1339.

Ryff, C.D., Keyes, C.L.M., \& Shmotkin, D. (2002). Optimizing well-being: The empirical encouentr of ewo tradition. Journal of Personality and Social Psychology vol. 82, 1007-1022.

Stuart, G.W. (2013). Principles and practice of psychiatric nursing. (10th edition). St.Louis: Mosby.

Suparmiati, A., Ismail, D., \& Sitaresmi, M.N., (2013). Hubungan Ibu Bekerja dengan Keterlambatan Bicara pada Anak. Sari Pediatri 2013 vol. 14(5):288-91.

Susmiatin, E.A., Keliat, B.A., \& Susanti, H. (2010). Pengaruh Terapi Kelompok terapeutik terhadap kemampuan Adaptasi pada Ibu Hamil di Kelurahan Balumbang Jaya Bogor. Tesis FIK Universitas Indonesia.

Townsend, M. C. (2009). Schizophrenia and Other Psychotic Disorder Essentials of Psychiatric Mental Health Nursing Concepts of Care in Evidence-Based Practice (sixth ed.). Philadelphia: F.A. Davis Company.

Trihadi, D., Keliat, B.A., \& Susanti, H. (2009). Pengaruh Terapi Kelompok Terapeutik terhadap Kemampuan Keluarga dalam Memberikan Stimulasi Perkembangan Usia Kanak-kanak di Kelurahan Bubulak Bogor. Tesis FIK Universitas Indonesia.

Varcarolis, E.M. (2010). Essential of Psychiatric Mental Health Nursing, A Communication Approach to Evidence-Based Care. Elsevier. Inc.

Walter, Keliat, B.A., \& Hastono, S.P. (2010). Pengaruh Terapi Kelompok Terapeutik terhadap Perkembangan Industri Anak Usia Sekolah di Panti Sosial Anak Kota Bandung. Tesis FIK Universitas Indonesia.

Winefield, H.R., Gill, T.K., Taylor, A.W., \& Pilkington, R.M (2012). Psychological well-being and psychological distress: is it necessary to measure both? Adelaide: Psychology of Wellbeing Springer open Journal Vol. 2:3.

Wiyata, D., Mustikasari \& Wardani, I.Y. (2014). Pengaruh Terapi Kelompok Terapeutik Remaja terhadap Pengendalian Emosi Marah pada Remaja di Kota Depok. Tesis FIK Universitas Indonesia. 